\title{
Scotland's public libraries are nothing but practical when it comes to deselection
}

Katie Rowley and Rebekah Willson

\section{The Occasion}

This is the result of thesis work undertaken at the University of Strathclyde during the 2016/2017 academic year.

\begin{abstract}
This paper is based on results from qualitative research into Scotland's public libraries collection development practices and the thoughts of library staff in regards to deselection (referred to in this paper as weeding). An open-text online survey promoted through professional newsletters, word of month, and social media, solicited rich, personal input from practicing library staff on the role, practice, and future of deselection in public libraries. From 36 responses, three main themes were developed: public perception, the role of governance, and continunity concerns. With pressure to provide the latest technology and published works for users, all in safe, usable spaces, Scotland's libraries are weeding to remain relevant and responsive.

Governance structures controlled policy and implementation of weeding practices, with respondents from Scottish public libraries overwhelming weeding via stock exchanges or with assistance from library headquarter teams/professional staff. The larger concern for collection development staff was having the budget, time and staff to make weeding a continuous, efficient process.
\end{abstract}

Authors

Katie Rowley is the Outreach Librarian for the National Oceanic and Atmospheric Administration Central Library located in Silver Spring, MD.

Rebekah Willson is an Associated Professor in the School of Information Studies at McGill University in Montréal, Canada.

Email: ktrwly@gmail.com 


\section{Introduction}

When material becomes damaged, irrelevant, or libraries are pressed for space, deselection becomes necessary and someone has to make a decision. At the centre of this oftunmentioned and silent service are the staff who perform the task of deselection, commonly referred to as weeding. This article asks the following questions: How do collection development staff in Scotland view weeding? What weeding methods or practices do public libraries in Scotland follow? What concerns collection development staff about the future of collection management, in particular, weeding? In the current evolution of library services that balance physical and digital material, this study concentrated on weeding print material to examine public library staff's thoughts and feelings toward weeding, the decision-making process, its implementation, and the various practices and methods. Scotland holds an enviable number of beautiful, Carnegie-built public libraries and a supportive population, yet research has neglected to explore this topic across the country which hopefully makes this survey of value to those practicing there today.

In Scotland, 1 in 2 people use public libraries and 77\% of those asked believed libraries to be important to the community (Peachey, 2017). With statistics like these, Scotland's weeding projects could be major influencers when it comes to how the public view and use public library spaces. With this responsibility, Scottish public libraries need to have clear policies, practices, and reliable research to support their decision-making. 


\section{Background}

Removing books seems counterintiuitive, so why weed at all? Answering the question, Johnson (2013) offers a list: "because [materials] are inaccurate, out of date, misleading, unused, or in poor condition...because [libraries] have run out of space or want to repurpose space for other uses" (p. 2). Slote (1997), an authority on weeding, also offers a list of seven reasons why weeding is a necessity: stimulate circulation, save space, save time, enhance appeal, establish credibility, respond to community need and interests, and make room for new technologies. Budget meetings and the ever more popular shared-space designs also play a role (Cottrell, 2013). These reasons aside, after a thorough weeding, the remaining books should be the most current, accurate and representative books. While the argument that circulation increases as a result of weeding has not been borne out in research (Dilevko \& Gottlieb, 2003; Banks, 2002), there is a need for relevant, attractive stock. This was identified by a study in New South Wales, Australia, which found condition of stock an importanct factor in how public libraries and communities can interact successfully with each other to improve library use and relevance. Those libraries with majority collection holdings aged fewer than five years recorded higher than state average circulation statistics (Jones, 2007). In this situation, a guidebook to Los Angeles from 10 years ago is removed because it's outdated, regardless of its "print or pixel" formatting (Palmer, 2012). Enforcing the idea of attractive, Dilevko and Gottlieb, quoted a participant using weeding as a means to combat the "dusty archives" stereotype (2013, p. 80). A final note on evaluation from a Norwegian weeding project found their adult non-fiction collection to be "the most obsolete category," holding irrelevant material like "'Daily Life Computing' from 1982" (Røgler, 2014, p. 384). 
Weeding is a regular and vital part of collection development (Johnson, 2013) even when the "majority of people see most books as permanently valuable" (Berry III, 2013, p. 10). There are considerable barriers to weeding, including: lack of time, lack of experience, public outcry, and differing evaluation criteria.

Evaluation criteria has yet to reach consensus in reviewed literature, but the commonly found CREW (Continuous Review, Evaluation, \& Weeding) Method, offers a type of guidebook to deselection by evaluating materials by year of copyright, last use, and condition (Larson, 2012). Another criterion guide similar to CREW is MUSTIE (Misleading, Ugly, Superseded, Trivial, Irrelevant, and Elsewhere), which is concerned with the book in hand versus an overall deselection policy, but has been cited as a practical guide to help libraries make those choices (Ford, 2015).

With criteria in place, library staff are then advised to "take the time to familiarize themselves with the circulation history, interlibrary loan requests, publication ages, and shelf availability for every part of the collection before diving headlong into the weeding process" (Boon, 2009, p. 327). Adding to this viewpoint by addressing what weeding is not, Goldsmith (2016) states it is not censorship, keeping your favorites (and weeding your dislikes), or circumventing the Code of Ethics by treating this task as best done quickly, with the easiest material to reach. Summarily, reviewed evaluation criteria follows the most basic principles of attractive and useful, allowing public libraries great flexibility in how they address deselection. This is were a policy or plan comes in.

Collection development plans, or management policies, are central to the "tasks of acquiring, organizing and managing library materials," (Gregory, 2011, p. 31) which is where deselection policies fit. They often start with looking at a library's inventory and assessing the 
collection as a whole; organizing and maintaining a stock collection that is flexible to patron needs while also open to resource sharing and alternative procurement to effectively serve the information needs of the community (Dixon, 2002).

Turning to Scotland specifically, collection management policies were found in $93.3 \%$ of local authorities surveyed, and of those, all urban and town policies included weeding components, with $80 \%$ of rural and $90 \%$ of mixed areas (Scanlon, 2012). Public libraries are represented by the Scottish Library and Information Council's (SLIC) recent Ambition \& Opportunity: A Strategy for Public Libraries in Scotland 2015-2020, but the treatise is focused on carrying Scotland's libraries into the future and does little to mention collection management practices aside from encouraging "resource sharing among all types of libraries for the purpose of achieving economical and efficient delivery of library services to the public" (Carnegie UK Trust, 2015, p. 39).

Tasked with determining what material to weed from their collections, library staff, with broad questions as to criteria, evaluation method and policy, are also balancing varying attitudes, opinions and thoughts on the practice of weeding. So, how do they weed?

\section{Methodology}

This paper is a partial replication of a previous study's email questionnaire (Dilevko \& Gottlieb, 2003), using selective questions and transforming them into an online survey, with a mix of open text and multiple-choice questions. This questionnaire included a small number of demographic questions to place respondents into broad categories (such as years of experience and gender), and limited numerical questions regarding number of library holdings, geographic location and area population. These captured contextual information and ranking criteria for 
analysis. Open text questions asked respondents about their library practices in weeding frequency, policies, collection sizes, and related activities including, reviewing circulation statistics, evaluating collection items for damage/age/relevance, and physically removing books from shelves. Open from 31 May to 1 July 2017 the survey had a total of 52 respondents and 36 response candidates for inclusion in the data set. Participant criteria for this study involved two conditions:

1. Participants were Scottish public library staff

2. As part of their position performed collection management activities The survey defined participants as 'public library staff' to offer all staff who perform deselection tasks the chance to take part, regardless of their title, as a variety of staff may be tasked with weeding. According to SLIC in their Ambition \& Opportunity strategy for public libraries there are over 600 libraries and other service points, such as mobile libraries, in Scotland (Carnegie UK Trust, 2015).

With the participation of human subjects, ethical approval was sought and granted before research commenced through the Computer Science and Information Departmental Ethics Committee at the University of Strathclyde. Participants were recruited through a variety of channels including social media, newsletters, email, and listservs using the principles of snowball sampling. This seemed appropriate as the number of library staff in Scotland who performed deselection activities is unknown and the understanding is that these tasks can be "hidden" within job descriptions, thus potentially including every member of staff at a public library (Atkinson \& Flint, 2001). 
Library and Information Research https://doi.org/10.29173/lirg795

Links to the online survery were sent to groups associated with the target population. To reach as large an audience as possible social media platforms Twitter and Facebook were used, both spaces of heavy library use for education and promotion of services (Vassilakaki \& Garoufallou, 2015). The survey dissemination also benefited from the help of associated professional organizations and groups. The Chartered Institute of Libraries and Information Professionals in Scotland (CILIPS) used their listservs to email CILIPS members and included it in their mid-June newsletter; SLIC emailed all 32 council authorities, and the Public and Mobile Library Group (PMLG), a specialist group within CILIP offered to share it among their members.

An anonymous link, which did not collect participants' IP addresses, was attached to each email, post or tweet with the request that the recipient after completing the online survey spread the survey to others who fit the criteria. Administered through the software program, Qualtrics, all data collected were anonymous and respondents were offered the chance to view aggregate data and study findings at the conclusion of the study through an email request to the researcher.

Compared to Dilevko and Gottlieb, the study's online survey posed eleven new questions; six questions underwent wording changes, but remained the same in substance; three were merged and five questions were unchanged for their clarity and relevance to the research questions (Appendix 1).

Limitations to the study include,

1. selection bias "towards the inclusion of individuals with inter-relationships", overemphasizing "cohesiveness in social networks" and missing those unconnected to the researcher's main chain of referral (Atkinson \& Flint, 2001, p. 2). 
Library and Information Research https://doi.org/10.29173/lirg795

2. having no known population numbers; SLIC offers the statistics of 423 staff with library qualification and 1,839 other staff in Scotland from the Chartered Institute for Public Financing and Accountancy (CIPFA) 2013-14 Actuals, but this data does not distinguish staff engaged in deselection tasks or narrow the numbers to Scotland alone (Carnegie UK Trust, 2015).

3. Platform unable to support follow-up questions for clarity or follow nuances in expression.

\section{Data Analysis}

Thematic analysis was the chosen qualitative technique through which to render the survey responses. Thematic analysis is defined for this study by Ayres (2008), who states:

Thematic analysis is primarily a descriptive strategy that facilitates the search for patterns of experience within a qualitative data set; the product of a thematic analysis is a description of those patterns and the overarching design that unites them (p. 868).

Ascribing to Braun and Clarke's 2013 treatise that thematic analysis is a method in its own right, the study followed their six phases to identify themes inductively and at a semantic level, with the research questions subject to evolution through the coding process. These decisions were made to allow for flexibility and a wholeness across the data set. The six phases are:

1. Familiarising yourself with the data

2. Generating initial codes

3. Searching for themes

4. Reviewing themes

5. Defining and naming themes

6. Producing the report 
Given the study's interest in gathering themes around perceptions of weeding and understanding how participants see weeding, qualitative research, in particular thematic analysis, was the natural choice. Analysis was achieved through using Qualtrics to filter and sort responses and NVivo software to pick out frequently used words, organize codes and find insights that became final themes.

\section{Findings and Discussion}

The study findings are discussed below, including demographics and library staff's stated weeding policies. Themes that emerged from the data will also be explored. These themes include: public perception, role of governance, and concerns for the future.

\subsection{Demographics and Weeding Practices}

Results from 36 respondents are explored below. First is the breakdown of collected quantifiable data as relates to geographic area, population served, and collection levels (Figures 1 and 2). The whole of Scotland was very well represented with at least one respondent from each region, with 12 responses coming from Northeast Scotland, Orkney and Shetland. Distribution of the survey revealed a concentrated area of responses from Northeast Scotland, Orkney, and Shetland. These could reveal a strong and highly involved professional network of library staff to be watched when discussing Scotland's public library future. 
Figure 1. Regions of Scotland with number of questionnaire respondents.

Highlands \& Islands

Edinburgh, Fife, \& East Scotland

Glasgow \& West Scotland

Northeast Scotland, Orkney \& Shetland

South Scotland

Tayside \& Central Scotland

Total: 36 respondents

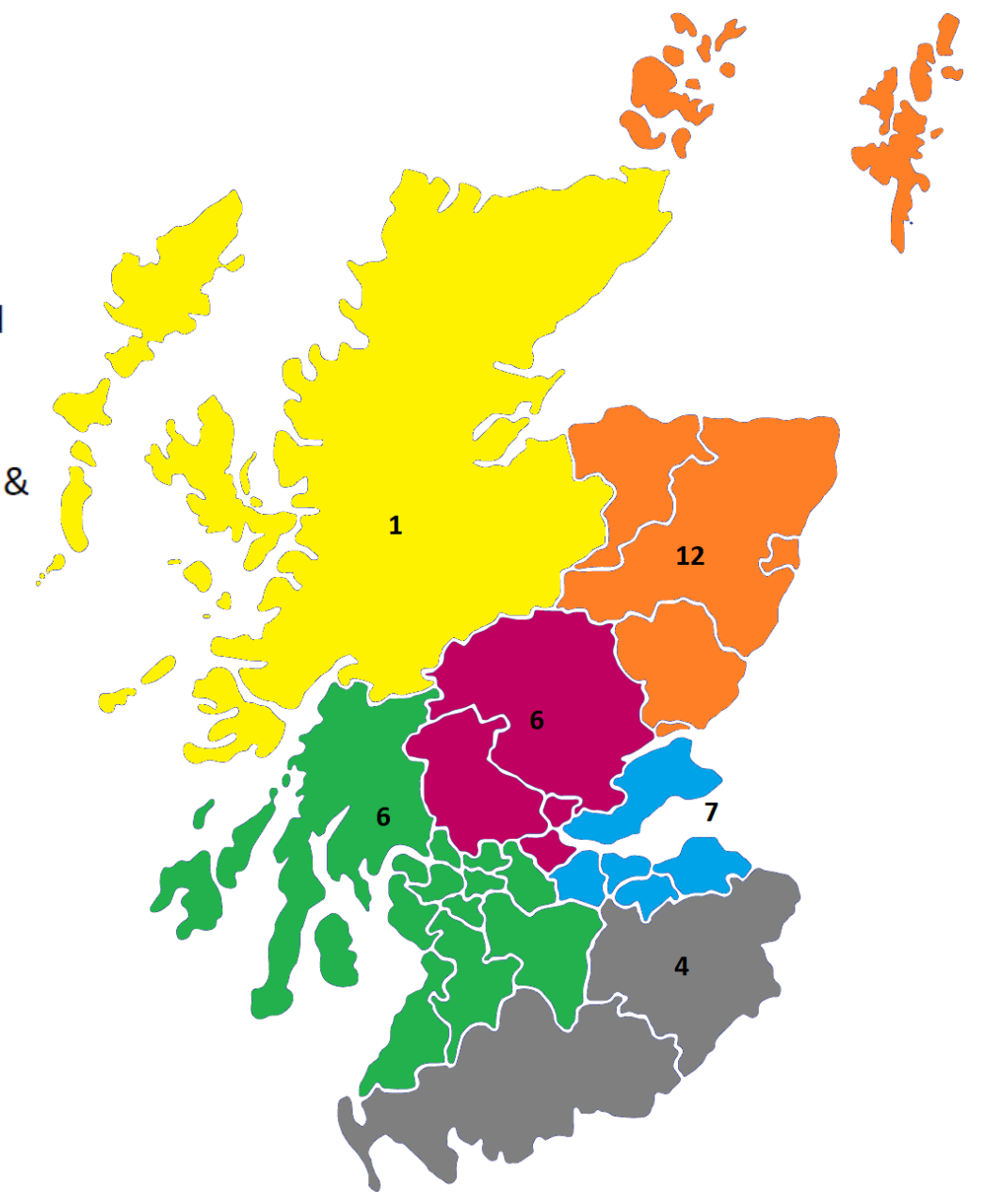

As libraries in Scotland are run by local council authorities, some rural with limited staff, these survey results are a promising snapshot of sentiment across the country. The next graphic (Figure 2) sets the approximate number of physical material Scottish libraries have, in their regions and with their community population levels. 
Figure 2. Numbers of physical materials in respondents' libraries.

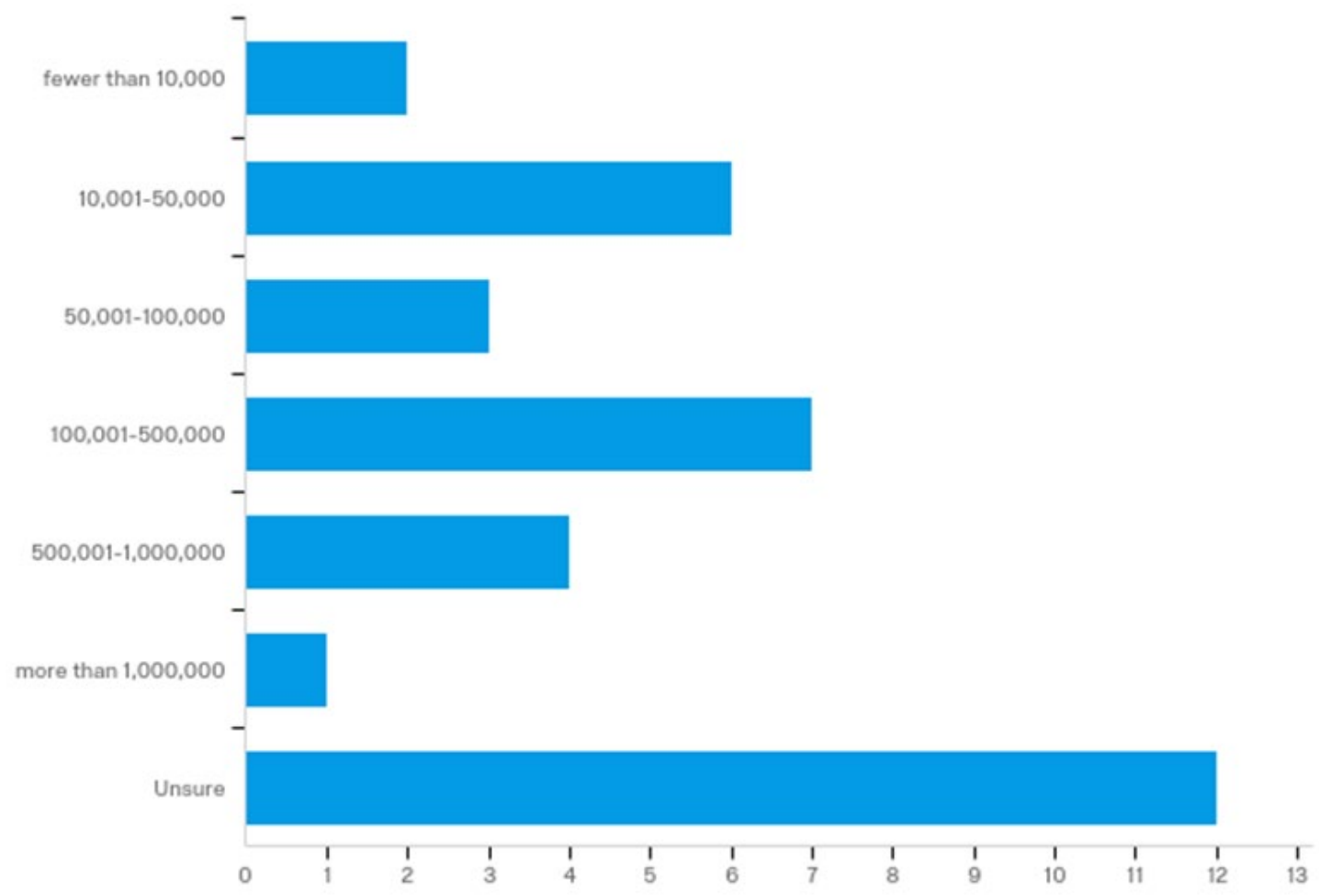

Concerning is the 12 respondents that felt unsure of the number of materials their library currently held. This is reflected also when respondents were asked the population level they served.

Respondents were asked to choose all reasons for weeding that applied to them, from a list of seven reasons (see Table 1). An option for 'other', with free text, yielded an additional two reasons: software recommendations and duplication. 


\begin{tabular}{|l|c|c|}
\hline \multicolumn{1}{|c|}{$\begin{array}{c}\text { Table 1: Reasons for weeding } \\
\text { Reasons }\end{array}$} & Number of Times Chosen & $\%$ \\
\hline Damaged or mouldy & 35 & $97.2 \%$ \\
\hline Low circulation of item & 32 & $88.8 \%$ \\
\hline $\begin{array}{l}\text { Misleading or factually } \\
\text { incorrect }\end{array}$ & 27 & $75 \%$ \\
\hline Superseded by another work & 27 & $75 \%$ \\
\hline Space considerations & 22 & $61.1 \%$ \\
\hline Age/Copyright date & 21 & $58.3 \%$ \\
\hline $\begin{array}{l}\text { No longer meets the library's } \\
\text { objectives }\end{array}$ & 19 & $52.8 \%$ \\
\hline Other: & 4 & $11.1 \%$ \\
\hline
\end{tabular}

On average, the 36 respondents chose approximately 5 reasons for weeding (5.2 basic average) and when asked to then rank, using radio buttons from 1-6, how important each reason was to weeding the respondents overwhelmingly choose damaged/mouldy as the number one reason for weeding. An 'other' option provided room for respondents to comment on space, with one saying, "I have limited access to secondary storage for items I want to keep but are no longer circulating." Another comment indicated the software CollectionHQ (an internet-delivered subscription service that helps libraries select, manage, promote and evaluate their stock), would help identify items "potentially grubby through use", which then could be replaced or discarded.

Respondents were asked as to the frequency of weeding as a practice. Weeding on a regular basis was mentioned 19 times explicitly in the responses. It was implied in several other comments that weeding is a daily occurrence or on a continuous basis. These regular weeding practices were often seen in conjunction with a rotation system, monthly, or conducted by dedicated library headquarters staff. It was noted front line staff would do daily physical checks to books returning. Irregular weeding was explicitly mentioned 10 times, but weeding was assumed irregular in several more instances, as seen by this comment "[it] depends from branch 
to branch." Irregular weeding respondents closely associated their weeding with space issues, time and staff constraints, "Different parts of the stock are weeded as time and space requirements dictate." One respondent mentioned wishing to weed more, especially the 6 copies of "guides for Thailand all published in the same year". Space availability was mentioned explicitly by 5 different respondents as to how often they weeded.

When asked if written guidelines were in use 63.89\% (23) answered yes, $27.78 \%$ (10) indicated no, and 8.33\% (3) were unsure. The guidelines or stock management policies not established were under review or currently being drawn up for three of the respondents, implying that a whole governance structure was responsible in this creation process (or lack thereof). Only one respondent indicated that while there was a service wide collection policy they did not refer to it when weeding either in disregard for its helpfulness and/or ultimate authority. Common to all stock policies that respondents detailed was the weeding of material due to age, condition, and circulation. Removal of stock that was damaged beyond repair was a universal finding. After this the age of items varied, with some commenting that items stationary for 18 months were weeded or exchanged; less for children's books. Others reviewed and possibly discarded all materials over 10 years old. One library had an 'inactive stock' guideline for branch libraries that stressed the importance of generating a list of inactive stock regularly to weed the collection. Some policies included the use of material's titles to judge for content that is "dated, inaccurate, misleading, or no longer timely".

Staff were found to be content with their policies for the most part, but when asked what they would change about their collection development policies, two responses from library staff clearly indicated a desire for the time, budget and staff "to run a weeding rotation where an area of the collection is weeded and refreshed in the same time period." The need for more staff, or 
Library and Information Research https://doi.org/10.29173/lirg795

better trained staff, was an important when reviewing respondents comments on confidence and mistakes in weeding. Training of staff on weeding guidelines was stressed in several points, such as,

It takes a bit of time for staff to get a feel for weeding, even with detailed guidelines. We list categories that are likely to get out of date quickly and try to give guidance on authors whose popularity has waned but customers are likely still to come back to. The Lib Sup team develop the skill and check over the weeding done by new members of staff until they get it.

Reflecting on this above statement, it can be found throughout the survey that library staff see a lack of confidence in other staff to weed or be empowered to weed. This is manifest in the stock policies and library headquarters support teams, who situate themselves as the final stop and relieve local branch staff of making tough decisions. Only obviously damaged material was seen as a common strand in the decision-making process, i.e. everyone was encouraged to remove these items.

\subsection{Public Perception}

The first theme to be explored is the public's perception and the public libraries role in the community given how library staff replied to survey questions, drawing connections between weeding practices, staff opinions, and how the library is viewed. Weeding was viewed by almost all survey respondents as increasing patron satisfaction and usage, mirroring the findings from Dilevko and Gottlieb (2003) of respondents claiming increased satisfaction (p. 94). Staff views were backed up by other researchers' findings as well in the case of weeding to improve collection appeal, attractiveness, and remain relevant to the needs of the community (Mandel, 2007; Palmer, 2012; Boon, 2009). Staff personal opinions of weeding play a major role in the theme of public perception, or more accuately, staff perception of the public. Concerned with 
how the library was seen through the collection, staff were adamant that shelf appearance and holding relevance were of vital importance. Several open-text responses highlighted the library's role in borrower recommendations, borrower knowledge and being "organic" and "everchanging" with weeding an essential component to avoid borrowers switching off or thinking the library offers "[substandard] items". The attractiveness of the library to patrons is reinforced by the following comment on shelf appeal, findability, space, and user-centered weeding,

Removal of tatty items means that our stock looks better, more attractive. People are more likely to browse "nice" books and borrow something different. I like some breathing space on the shelf. Removal of tatty/old/damaged items mean more space for display.

New stock could be hidden, library staff observed, when the collection is overwhelmed by titles that don't circulate and look "old and worn". This increase in findability in turn increases print material usage "as the library looks much more cared for and inviting" and testimony from one librarian in the unlooked-for benefit of water damage said,

this has been an eye opener to me, I thought more made for much more borrowing but I found out this was the reverse when I had an accident at my old site and lost a third of my books in a water damage accident. The ones left had more space and the users found it easier to find and borrow [when there were] less books!

Findability is the key to patron satisfaction, one respondent asserts, not shelf tidiness or weeding. Shelves "mainly of unused and unwanted material" make finding good material harder and "If people don't see the new titles they think the library is out of date and will go elsewhere for their books." This perceived threat of library users going elsewhere for their reading entertainment is interesting for the assessment of libraries as in competition with bookstores, such as Amazon. "Libraries need to hold relevant, up to-date, quality materials that appeal to readers and meet borrower needs." If not seen as equal or better than a paid-for service, it is assumed library relevance will falter. 
With libraries striving to be percieved as usable and welcoming, weeding because of space constraints was mentioned several times as the impetus to create a deselection policy, revealing issues with allocations to print collections in competition with community wants and budget. "The shelf space available...is shrinking as other [facilities] are introduced and it is essential that the quality (physical and readability) is maintained at service points"; however, "we want to be providing the public with what they want." Libraries appeared to be struggling in adding more technology and other shared services into finite building space. New stock can also be inserted here, as a space consideration when weeding, since "new stock [is] coming in weekly." Weeding plays an important role here in helping to maintain the collections integrity in the face of fewer physical resources.

Library staff reaffirmed that they are here to serve a mission that places customers at the heart of a free, accessible, resource-sharing, community organization. Survey respondents mentioned customer needs and desires, with weeding "necessary" to help libraries "engage with [our] customers and deliver an excellent service." Staff's concern for and pride in serving customers was seen in equal measure in the responses. One respondent reported,

We have high standards in our libraries and have a commitment to our customers that items will be of good quality, relevant and meet the demands of customers. We have one of the hardest working stock collection in Scotland according to cipfa [Chartered Institute of Public Finance and Accountancy] stats and weeding plays a crucial role here. Customers are able to find new stock of interest and shelves are not overly burdened with stock that is no longer issuing.

Offering materials to customers and ensuring that those materials are of the best quality is a major part of library services according to staff. It is noted that some library users visit on a "regular basis" for their entertainment and know that they will always find something new. This responsibility on library staff then is to get to know their users, their likes and needs, to provide 
them with the best possible assistance. Format matters as well, "Not all customers will want to use ebooks or online resources but it's important to make provisions for those that do," notes one respondent. Knowing your borrowers and then basing selection and evaluation choices on this includes the reasons libraries keep materials instead of weeding. Weeding for public perception though carries a chance of collection imbalance.

Carrying over the idea of a user-centred library mindset, respondents stated repeatedly that they would save or find a way to keep certain stock if it had local significance, a foreseeable rise in popularity due to media attention/global trend, or if it was a particular favourite. One comment emphasised the need to keep certain material even if they circulate rarely as "there are directives from our HQ on collections we should have, e.g Healthy Reading, Skills Zone etc, these may not go out as often but are necessary to a small part of the community if they come in.” Aside from keeping a quota of low circulating, but essential material, it was mentioned strongly by one respondent that "a lot" of library staff are not 'experienced' enough to weed appropriately,

[S]taff [...]do not appreciate that sometimes 'old' titles require to be kept. [F]or instance we had a copy of a book entitled pure, white and deadly which was a 1986 copy. Shortly after saving it as I felt it was one of the few titles (at the time) on the subject - the title was referenced in a programme on the $\mathrm{BBC}$ and we were inundated with requests for it. The title was currently out of print so it proved valuable to keep it in stock.

Last copies or reference material were also mentioned as criteria that could exempt print material from being weeded. One respondent used their power to transform lending stock to reserve stock for older material "unlikely to be replaced by new stock. For example books on old clockmakers, art books, old crafts etc." The use of secondary storage and closed stacks helped these library staff to convert and save material that was still of value, either permanently or until alternative material was available and a suitable replacement. 
One exception to this was a respondent who noted that they had observed staff hoarding "collections of items which were in very poor condition behind the scenes as readers often requested them." In their opinion, this reflected negatively on the library, even if the materials kept were popular with users. This could be a side effect of budget restrictions on purchasing replacement copies, but it also could be showcasing library staff reluctant to weed.

In all steps of weeding the level of review was minimal, with a two-step process, between the branch library and main library or headquarters. In some cases, a single person decided. This was felt by respondents to be enough and users were not consulted in the weeding process. However, users were sometimes informally included in the weeding process by being given a final opportunity to borrow books. Staff would create "last chance" displays of candidate material, with one respondent commenting, "It is amazing how many library users go straight to [a] book display and grab items which would otherwise have been overlooked." But if this display fails to entice readers, the book is withdrawn and in a number of cases sent on for final decisions, exchanges, or reserve stock holdings at a central library or headquarters.

Do these results have a connection to how many staff are unsure of stock levels and population levels? Using only computer reports, physical inspection of returned stock, and lacking written policy would explain partially why staff are unaware of full stock numbers and potential population numbers as they are only dealing with a subset of both. A symptom of this could be the least popular reason to weed 'no longer meets library's objective'. Indications from staff are that Scottish libraries are subject to heavy turnover in stock which prioritizes accuracy, relevance, and circulation (regardless of age, if not condition). Thus, proving public perception to be a main theme and reinforcing the study in New South Wales, Australia (Jones, 2007). 


\subsection{Role of Governance}

The second theme divines the 'who' in the 'how' of the weeding process. Through analysis of how weeding was accomplished in Scotland's public libraries it became evident that a governance structure dictated many aspects of weeding practices with most staff referring to a management level for weeding decisions. When asked, respondents overwhelmingly indicated that weeding was a collective team effort, that "every member of staff is instructed on...and is expected to carry it out". Library headquarters or a librarian were listed in tandem as the next step for decision-making. "Branch staff all participate in weeding for condition but this is reinforced by main library staff who look at relevance/series/possible replacement/age." Others noted that software like CollectionHQ can identify stock, but then it is the "professional librarian" who makes the decision if material should be removed.

When asked where respondents did their weeding, the majority (14) weeded their main place of work, few managed teams of librarians or issued weeding guidelines authority wide, indicating a central power. This highlighted the separation of weeding between headquarters and branch/main libraries, with headquarters a very distinct, different space. Of the 36 respondents, the equal number of staff from headquarters and main libraries shows its central role and influence in governing weeding practices (see Table 2). Goldsmith's (2016) crash course on weeding, showing how weeding must be part of not just local, but all libraries in a system, is upheld by the survey responses. 
Table 2. Location of employment.

\begin{tabular}{|l|c|} 
Place of Work & $\begin{array}{c}\text { Number of } \\
\text { Respondents }\end{array}$ \\
\hline Main library & 9 \\
\hline Branch & 7 \\
\hline $\begin{array}{l}\text { Between } \\
\text { branch and } \\
\text { main }\end{array}$ & 7 \\
\hline Headquarters & 9 \\
\hline $\begin{array}{l}\text { Between } \\
\text { branchs }\end{array}$ & 4 \\
\hline \multicolumn{1}{|c|}{ Total } & 36 \\
\hline
\end{tabular}

Mentioned in the previous section, the level of review in public libraries is often one or two-tiered, with the professional librarian or assistant librarian making the final decisions as to what will be weeded. It was noted in several comments that all staff can pull damaged material, but for several libraries an individual and a team from headquarters, "Exchanges team”, in a popular option, would make weeding decisions together.

The frontline lending desk staff weed their own Libraries for items that are no longer issuing with them. These are returned to Library HQ where they are assessed by the Libraries Support team as to whether they should be withdrawn or kept in our pool collection to go out to other Libraries.

In an exchanges system, print material identified at the local branches is removed if damaged/mouldy, but if not sent on to a pool of rotating stock for better luck at another library. "Something may not issue in one branch but if moved it may issue in another," is the philosophy behind this practice. While library stock can wear out quickly, the exchanges process allows for all stock to be reviewed and "new" stock to be brought in with one comment underlining the importance of rotating stock before withdrawing it. Exchanges are also good for budgets, with one respondent saying, "I like to do the weeding myself as it helps inform the type of books I purchase for the collection. Our print material budget has taken a big hit this year so it is not so 
Library and Information Research https://doi.org/10.29173/lirg795

easy to simply weed and replace titles.” The general consensus from library staff regarding the financial outlook of their libraries was of caution. It appeared unlikely that print materials funding or new software/radio-frequency identification (RFID) tags would be possible with current budgetary factors, even if those advancements would make a positive difference in selection/deselection of material and improve the quality of library stock. Moreover, "Books tend to be kept perhaps longer that they should for fear of empty shelves."

\subsubsection{Qualifications}

While this survey did not ask for library staff to identify their qualifications or title the accepted weeding process frequently deferred weeding decisions to professional librarians, library headquarters or another senior person. Emphasising the role of governance, this choice to move weeding to a "management level" was noticed throughout the survey in every aspect of the deselection process, e.g. "If the item to be weeded is part of a series/ a last copy in stock/ or staff are unsure whether to weed, the item is passed to a qualified librarian (management level) who then makes the final decision."

Management level survey respondents were recognizable through declarative states like, "I manage", "I oversee", "I issue", yet they appeared to be in the minority and when discussing the decision to weed telling comments, like the one below, painted a less confident and empowered library staff.

All staff need to be aware of the expectations and guidelines regarding weeding and this may [give] some more confidence that what they are removing is correct. It would stop the "humming and hawing" about whether something should be removed and speed on the process. Often when books are returned and are checked prior to re-shelving it's clear that they should be removed e,g damaged, pages ripped, coffee spilled over pages and they need to be removed at this point as well however not all staff do this. 
Library and Information Research https://doi.org/10.29173/lirg795

The chance of human error is always there as well and one respondent noted that some donated material that passes through library headquarters has to be rescued, with "training or re-training" prescribed to enforce policies. Highlighting this need for training and transitioning the conversation to the future, one respondent advocated for technological innovations and software since "professional staff numbers are dwindling" and efficiency is key. Another expressed concerns about changing governance structures and the "inevitable" volunteers weeding collections with no experience or qualification.

Overall, weeding appears to be carried out simultaneously at local and regional levels, emphasisng a system-wide effort. With structures of decision-making in place regarding weeding, the survey respondents reinforce the importance of having a policy in the face of public inquiry or challenge (Metz \& Gray, 2005). This policy structure and organizational process implies that libraries are reacting continuously to public demands and using a sharing/floating collection to answer everyone's needs, which in this case requires an "intelligent" approach to weeding (Goldsmith, 2016, p. 70). It can be seen from survey responses that this setup benefits libraries on a local level, saving time and moving materials in a responsive manner, making weeding a less daunting and more integrated function. Scotland's libraries can benefit from this structure, but policies and subsequent training of staff needs to be in place to take full advantage of it. 


\subsection{Concerns for the Future}

The third theme explored was library staff's concern about sustaining deselection practices with fewer resources, especially budgetary. Survey respondents are currently relying on, and adapting well, to using specific software for weeding tasks, with CollectionHQ mentioned by name throughout the survey by library staff and management. Reports run through CollectionHQ were identified as the incentive for weeding in several instances and one respondent noted, "We have made use of [CollectionHQ] to move stock around the community library network - it can highlight what titles could be used elsewhere and which items may be ready for disposal." One library though, discussing reports, challenged the wisdom of software prescribed stock levels,

We are also told that we should use reports to reduce our stock to a level that reflects our borrowers usage - this would mean that we wouldn't have a choice of books for casual browsers. We tend to ignore this and keep the shelves well stocked.

Another respondent added that their libraries "are required to run 'dead stock' reports which are determined by certain criteria through our use of V-Insight (V-Eye-Q).” V-eyeQ is a collection management tool from the company Infor and offers performance metrics and even advice on weeding (Infor, 2017). The cost of these systems did have some respondents concerned, "library budgets will not support the kind of technology that would make [automation] useful," technology like RFID tags.

The idea that software is a useful, valuable tool is echoed throughout the survey responses, e.g. "allows professional input $[\ldots]$ without...the time consuming [handling] of every book". The prevalence of management systems makes the total avoidance of automation illogical and impractical, even if libraries only update their library management systems without an extra collection management service because of cost. However, there is a firm conviction among 
Library and Information Research https://doi.org/10.29173/lirg795

library staff that software and automation is only as good as making suggestions for a person to implement, or not. A person's judgement was held critical to the weeding process, "Staff will know if there is local relevance, whether an item is a hot topic of the day, whether an item is a potential book group title or a classic that should be retained." Real concern is shown when staff think of the changing professional landscape of libraries. Fears over volunteers weeding with abandon, as mentioned above, are coupled with financial concerns.

When asked how they felt ebooks and electronic resources would affect the future of weeding in public libraries, respondents asserted that the two should not affect each other, as they are different formats with different audiences. Still other respondents called out that physical stock will still be around and need to be weeded, regardless of ebooks. Anderson (2016) notes, licensing ebooks for perpetual use is an option libraries (academic, in this case) struggle to achieve, reflecting on this a survey respondent commented that most ebooks are bought for a limited time and thus are "self-weeding," implying they don't require collection development practices as books just disappear. The idea of a self-weeding collection may be appealing, but licenses are not user-centered or interested in balanced collections, thus requiring staff time and curation.

The popularity of ebooks was discussed as well, with several respondents testifying that ebooks were plateauing or on the decline, and that borrowers still liked physical books. Access barriers were brought up, as many library users do not have a device capable of online reading/borrowing, and ebooks cannot be interlibrary loaned or even be considered 'owned' by the library since licensing options are restricted. Limited stock options were also a frustration and reason to downplay ebooks. 
Yet, a handful of respondents commented that ebooks did have an impact on their physical stock, if not how it is weeded. "In order to offer ebooks, funds that would normally be spent on physical collections are allocated to ebooks so we need to make our physical stock work harder." Others asserted in certain cases ebooks or e-resources would be purchased as a replacement for a physical item. The appeal of ebooks and e-resources is the ability to offer another format and as one respondent says, "I have read books through Project Gutenberg that I would probably not have found browsing shelves in this country. Many of these would not survive weeding due to their being "out-dated"."

While there was a resounding "No!" to the idea that staff would be replaced by automated software, the acceptance of software as a tool, a helper, and data resource was equally represented in the survey responses, with most mentioning Scottish-based CollectionHQ as their go-to system, implementing evidence-based analysis of collections to weed, replace, and transfer materials. The biggest takeaway concerning the future though is budgetary restrictions on libraries and the fear of losing qualified and experienced staff through the efficiency of technological advancement. Having print material "work harder", as one respondent wrote, in the face of uncertainty is the future that libraries are already dealing with. The focus on budget, while not a new challenge, is impacting the ability of public libraries to fulfil their missions to provide accurate, informative, and entertaining materials by impeding weeding and selection processes.

\section{Conclusion \& Recommendation}

In conclusion, the literature review showed that weeding research has been neglected, especially in the case of public libraries, and giving voice to Scotland's library staff highlighted 
the challenges and opportunities they face. Three main messages have been observed throughout this survey,

1. Deselection in public libraries in Scotland is part of a larger view on how the library is perceived in the community,

2. It relies heavily on the governance style of each area, and is not overly concerned about the future of automation and weeding software,

3. There are concerns about the financial and staffing burdens created by the current economy, communal space demands, and format changes.

The survey data collected also hit on several points of desired strategy and policy changes for public libraries. The need for more training was highlighted as key to implementing deselection in a positive and effective manner. A suggested solution for a regular weeding practice and increased weeding by staff was policies that have clear, actionable guidelines. Using software for deselection decisions was widely accepted as well, and staff opinion held that in conjunction with professional interpretation it was a valuable tool and time-saver. The results from this study should be used by Scotland's public library administrations as a starting point to discover areas within their policies that need attention, especially deselection decision-making.

Further research in the area of weeding, and for Scotland in particular, could look more closely at the relationship between professional qualifications and deselection decision-making. While this survey did not delve into the titles of professional qualifications of respondents, library and information studies degree granting institutions would doubtless be interested in the impact of advanced education in the field. 


\section{References}

Anderson, E. (2016). Print to electronic: The library perspective. Publishing Research Quarterly, 32(1), 1-8. doi:10.1007/s12109-015-9440-5

Atkinson, R. \& Flint, J. (2001). Accessing hidden and hard-to-reach populations: Snowball research strategies. Social Research Update, 33. Retrieved from http://sru.soc.surrey.ac.uk/SRU33.html

Ayres, L. (2008). Thematic coding and analysis. In Given, L. M. (Ed.), The SAGE Encyclopedia of Qualitative Research Methods. (pp. 867-868). Thousand Oaks: SAGE Publications.

Banks, J. (2002). Weeding book collections in the age of the Internet. Collection Building, 21 (3), 113-119. doi:10.1108/01604950210434542

Berry III, J.N. (2013). The weeding war/Blatant Berry. Library Journal, 138 (18), 10, 1 - 3.

Boon, B. (2009). Using the CREW method to enhance public and school library collections. Journal of Access Services, 6 (3), 324-336. doi:10.1080/15367960902894179

Braun, V. \& Clarke, V. (2013). Successful qualitative research: A practical guide for beginners. London: Sage.

Carnegie UK Trust. (2015). Ambition \& opportunity: A strategy for public libraries in Scotland 2015-2020. Retrieved from https://www.carnegieuktrust.org.uk/publications/nationalstrategy-for-public-libraries-in-scotland/

Cole, N. \& Usherwood, B. (1996). Library stock management: Policies, statements and philosophies. Public Library Journal-Public Libraries Group, 11 (5), 121-125.

Cottrell, T.C. (2013). Weeding worries, part 1: Books. The Bottom Line: Managing library finances, 26 (3), 98-102. doi:10.1108/BL-06-2013-0015 
Library and Information Research https://doi.org/10.29173/lirg795

Dilevko, J. and Gottlieb, L. (2003). Weed to achieve: A fundamental part of the public library mission? Library Collections, Acquisitions, and Technical Services, 27 (1), 73. doi:10.1080/14649055.2003.10765897

Dixon, D. (2002). Collection management. In Dewe, M. (Ed.) Local studies collection management (pp. 87-104). Hants: Ashgate.

Ford, D.B. (2015). To weed or not to weed? Criteria to ensure that your nonfiction collection remains up to date (Everyday Librarian). School Library Journal, 61 (8), 13.

Goldsmith, F. (2016). Crash course in weeding library collections. Santa Barbara: Libraries Unlimited.

Gregory, V. L. (2011). Collection development and management for 21 st century library collections: An introduction. New York: Neal-Schuman.

Infor. (2017). Library \& information solutions. Retrieved from https://www.infor.com/industries/public-sector

Johnson, P. (2013). Is weeding an unnatural act? Technicalities, 33 (5), 2-4.

Jones, C. (2007). Maintaining a healthy library collection: The need to weed. Australasian Public Libraries and Information Services, 20 (4), 170-173.

Larson, J. (2012). CREW: A weeding manual for modern libraries. Austin, TX: Texas State Library and Archives Commission. Retrieved from https://www.tsl.texas.gov/ld/pubs/crew/index.html

Mandel, L. (2007). An essential practice. Library Journal, 132 (6), 59.

Metz, P. and Gray, C. (2005). Public relations and library weeding. The Journal of Academic Librarianship, 3 1(3), 273-279. doi:10.1016/j.acalib.2005.01.005 
Library and Information Research https://doi.org/10.29173/lirg795

Palmer, M. (2012). E-book collection development in public libraries: a case study of the Essex experience. In Marshall, A. and Fieldhouse, M (Eds.) Collection Development in the Digital Age (pp. 211-221). London: Facet Publishing.

Peachey, J. (2017) Carnegie UK Trust: Shining a light-country factsheet (Scotland). Retrieved from https://www.carnegieuktrust.org.uk/shining-a-light/

Røgler, J. (2014). The case for weeding: The Buskerud bandits' contribution to a knowledgebased discarding practice in Norwegian public libraries. Journal of Library Administration, 54 (5), 382-402. doi:10.1080/01930826.2014.946752

Scanlon, R. (2012). An investigation of the collection management policies of Scottish public libraries (Unpublished MSc dissertation). University of Strathclyde, Glasgow. Retrieved from https://local.cis.strath.ac.uk/research/publications/papers/strath_cis_publication_2666.pdf

Slote, S. J. (1997). Weeding library collection: Library weeding methods ( $^{\text {th }}$ ed.). Englewood, CO: Libraries Unlimited.

Vassilakaki, E. \& Garoufallou, E. (2015). The impact of Twitter on libraries: a critical review of the literature. The Electronic Library, 33 (4), 795-809. doi:10.1108/EL-03-2014-0051

\section{Acknowledgements}

The authors acknowledge the Chartered Institute of Libraries and Information Professionals in Scotland (CILIPS), the Scottish Library and Information Council (SLIC), and the CILIP Public and Mobile Libraries Group for their assistance in promoting and distributing the survey. 


\section{Appendix 1}

Survey Questions and Response Choices

\begin{tabular}{|c|c|}
\hline Question & Answer Choice \\
\hline Consent Form & Yes/No \\
\hline $\begin{array}{l}\text { Are you a Scottish public library staff member with a role in } \\
\text { collection development and deselection (referred to in this } \\
\text { questionnaire as 'weeding')? }\end{array}$ & Yes/No \\
\hline Please select your age group & $\begin{array}{l}18-24 \\
25-34 \\
35-49 \\
50-69 \\
70+\end{array}$ \\
\hline Please select your gender. & $\begin{array}{l}\text { Male } \\
\text { Female } \\
\text { Other } \\
\text { Prefer not to say }\end{array}$ \\
\hline Please select your region. & $\begin{array}{l}\text { Edinburgh, Fife, \& East Scotland } \\
\text { Glasgow \& West Scotland } \\
\text { Highlands \& Islands } \\
\text { Northeast Scotland, Orkney \& } \\
\text { Shetland } \\
\text { South Scotland } \\
\text { Tayside \& Central Scotland } \\
\text { Other, please specify }\end{array}$ \\
\hline Please select the population range your library serves. & $\begin{array}{l}\text { less than } 10,000 \\
10,001-50,000 \\
50,001-100,000 \\
100,001-500,000 \\
\text { more than } 500,000 \\
\text { Unsure }\end{array}$ \\
\hline $\begin{array}{l}\text { How many print materials does your public library currently } \\
\text { have? }\end{array}$ & $\begin{array}{l}\text { fewer than } 10,000 \\
10,001-50,000 \\
50,001-100,000 \\
100,001-500,000 \\
500,001-1,000,000 \\
\text { more than } 1,000,000 \\
\text { Unsure }\end{array}$ \\
\hline $\begin{array}{l}\text { What are the reasons that you weed the current print material } \\
\text { contained in your library's collection? Please select all that } \\
\text { apply. }\end{array}$ & $\begin{array}{l}\text { Damaged or mouldy } \\
\text { No longer meets the library's } \\
\text { objectives } \\
\text { Low circulation of item } \\
\text { Age/Copyright date }\end{array}$ \\
\hline
\end{tabular}


Library and Information Research https://doi.org/10.29173/lirg795

\begin{tabular}{|c|c|}
\hline & $\begin{array}{l}\text { Misleading or factually incorrect } \\
\text { Superseded by another work } \\
\text { Space considerations } \\
\text { Other: }\end{array}$ \\
\hline $\begin{array}{l}\text { Rank the criteria that you use to weed the print material in the } \\
\text { collection of your library from most important to least important } \\
(1=\text { most important, } 6=\text { least } \\
\text { important). }\end{array}$ & $\begin{array}{l}\text { Damaged or mouldy } \\
\text { No longer meets the library's } \\
\text { objectives } \\
\text { Last circulation date } \\
\text { Copyright date } \\
\text { Misleading or factually incorrect } \\
\text { Superseded by another work }\end{array}$ \\
\hline $\begin{array}{l}\text { Please use this space if you have additional criteria or } \\
\text { comments. }\end{array}$ & Open Text \\
\hline Where do you work? & $\begin{array}{l}\text { Branch library } \\
\text { Main library } \\
\text { Between several branch libraries } \\
\text { Between the main library and } \\
\text { branch libraries } \\
\text { Other, please elaborate: }\end{array}$ \\
\hline Do you do weeding for more than one library? & $\begin{array}{l}\text { No, I weed at the same library } \\
\text { where I work } \\
\text { Yes, I weed between several branch } \\
\text { libraries } \\
\text { Yes, I weed between a branch and a } \\
\text { main library } \\
\text { Other, please elaborate: }\end{array}$ \\
\hline $\begin{array}{l}\text { How often do you weed the print material collection of your } \\
\text { library? Is it on a regular basis, or irregular? }\end{array}$ & Open Text \\
\hline $\begin{array}{l}\text { If regular, what is the usual frequency of weeding? If irregular, } \\
\text { when was the last time that the collection of your library was } \\
\text { weeded? }\end{array}$ & Open Text \\
\hline $\begin{array}{l}\text { Does your library follow any written guidelines for weeding the } \\
\text { print material collection of your library? }\end{array}$ & $\begin{array}{l}\text { Yes } \\
\text { No } \\
\text { Unsure }\end{array}$ \\
\hline $\begin{array}{l}\text { If yes, what are these guidelines? If no or unsure, what practices } \\
\text { or methods does your library follow? }\end{array}$ & Open Text \\
\hline $\begin{array}{l}\text { Who participates in the weeding process? For example, is it } \\
\text { generally one person or a collective team effort? How does this } \\
\text { process work? Give as much detail as possible. }\end{array}$ & Open Text \\
\hline
\end{tabular}


Library and Information Research https://doi.org/10.29173/lirg795

\begin{tabular}{|l|l|}
\hline & \\
\hline $\begin{array}{l}\text { Is there a chance for other members of the library staff or } \\
\text { members of the community to review material that has been } \\
\text { designated as "to be weeded" before it actually is finally } \\
\text { weeded? How does this review process work? For } \\
\text { example, is there one level of review or multiple review levels? }\end{array}$ & Open Text \\
\hline $\begin{array}{l}\text { What are your personal attitudes, opinions, thoughts on } \\
\text { weeding? }\end{array}$ & Open Text \\
\hline $\begin{array}{l}\text { Have you ever personally saved a book or books that should } \\
\text { have been weeded? If so, why did you save this book or books? }\end{array}$ & Open Text \\
\hline $\begin{array}{l}\text { Do you personally believe that weeding increases book usage } \\
\text { and/or patron satisfaction? If yes, what is your reason for } \\
\text { thinking this? If no, why not? }\end{array}$ & Open Text \\
\hline $\begin{array}{l}\text { If you could personally make changes in your procedures for } \\
\text { weeding books in your collection, what aspects of your weeding } \\
\text { procedure would you like to change and why? }\end{array}$ & Open Text \\
\hline $\begin{array}{l}\text { How do you personally think ebooks and electronic resources } \\
\text { affect the future of weeding in public libraries? }\end{array}$ & Open Text \\
\hline $\begin{array}{l}\text { Do you think the future of weeding is automation, i.e. a } \\
\text { computer program will decide which books to weed based on } \\
\text { pre-selected data like last circulation date? }\end{array}$ & Open Text \\
\hline $\begin{array}{l}\text { Is this concerning for you or not? If yes, what are you concerned } \\
\text { about? If not, why not? }\end{array}$ & Open Text \\
\hline $\begin{array}{l}\text { Would you like to receive the results of this study or be notified } \\
\text { if this research will be published? }\end{array}$ & Yes/No \\
\hline
\end{tabular}

